\title{
The Establishment of School Social Work in Austria - From a Project to a Regular Offer
}

Arno Heimgartner ${ }^{* 1}$ And Stephan STING ${ }^{2}$

$\approx$ The contribution introduces the present situation and the basic challenges of school social work in Austria. Starting with the perception of a developing "knowledge society" (Höhne, 2004), school is seen as a life place at which social subjects and problems occur and are made manifest. The analyses are based in particular on empirical studies by the University of Klagenfurt (Sting \& Leitner, 2011) and the University of Graz (Gspurning, Heimgartner, Pieber, \& Sing, 2011), which were carried out in school social work facilities of Carinthia and Styria, but they also include Austrian-wide research projects. A methodical view is presented along the main target groups "pupils", "teachers" and "parents", and the basic orientations are discussed. The thematic analysis characterises school social work as a multi-thematic service (e.g., conflicts, love, problems at school, problems of the family) that needs to oppose the reduction to single problem areas such as drug abuse or violence. The structural analyses render visible the meaning of spatial conditions, personnel competence and the social-spatial network. Finally, the possibilities of a lasting implementation of empirical research in school social work are discussed.

Keywords: School social work; Austria; Social pedagogy; Evaluation

$1{ }^{\star}$ Corresponding author. Universität Graz, Institut für Erziehungs- und Bildungswissenschaft, Graz, Austria arno.heimgartner@uni-graz.at

2 Alpen-Adria Universität Klagenfurt, Institut für Erziehungswissenschaft und Bildungsforschung, Klagenfurt, Austria Stephan.Sting@aau.at 


\section{Vzpostavitev socialnega svetovalnega ${ }^{3}$ dela $\mathrm{v}$ avstrijskih šolah - od projekta do redne ponudbe}

\section{Arno Heimgartner and Stephan Sting}

$\approx \mathrm{V}$ prispevku so predstavljeni trenutno stanje in izzivi socialnega dela $\mathrm{v}$ avstrijskih šolah. Če za izhodišče vzamemo razvijanje »družbe znanja« (Höhne, 2004), je šola življenjski prostor, v katerem se socialni problemi pojavljajo in postanejo vidni. Analiza temelji na empiričnih raziskavah, ki sta jih v šolskih svetovalnih službah na območju avstrijske Koroške in Štajerske izvedli Univerza v Celovcu (Sting \& Leitner 2011) in Univerza v Gradcu (Gspurning, Heimgartner, Pieber, \& Sing 2011). Poleg teh raziskav so vključeni tudi drugi večji avstrijski raziskovalni projekti. Metodološki pristop je zajel vidik treh glavnih ciljnih skupin - »učenci«, »učitelji« in »starši « - ter analizo temeljnih usmeritev socialnega dela. Tako so v prispevku analizirani posegi te nove storitve $\mathrm{v}$ šolskem kontekstu (na primer razreševanje konfliktov, ljubezen, težave učencev v šoli, njihove težave doma). Šolsko socialno delo se ne ukvarja samo s problemi, kot je zloraba drog ali nasilje. Prek strukturne analize so prikazani pomen prostorskih pogojev za izvajanje tega dela, osebne kompetence izvajalcev in socialno-prostorska mreža te nove storitve. Na koncu so obravnavane možnosti trajne implementacije empiričnega raziskovanja na področju šolskega socialnega dela.

Ključne besede: šolsko socialno (svetovalno) delo; Avstrija; socialna pedagogika; evalvacija

3 V nemškem govornem področju se v zadnjih letih kot nadredni izraz, ki zajema širše področje vzgojnega, svetovalnega in socialnega dela, uveljavlja izraz socialno delo. V kontekstu tega prispevka je treba izraz socialno delo razumeti v smislu pri nas uveljavljenega šolskega svetovalnega dela, ki pa se v Avstriji šele razvija. 


\section{Introduction}

During the past two decades, we have seen a massive expansion of school social work in German-speaking countries in Europe. Following earlier developments in Anglo-Saxon and Scandinavian countries, social work has been established in German-speaking countries as an additional indispensable element of the school system (Huxtable \& Blyth, 2002).

The transformation to a "knowledge society" (Höhne, 2004) leads to an increase in societal demands with regard to school and education. The general increase of the level of education, as well as the growing importance of educational certificates and cultural capital, implies that most adolescents consider "going to school" as a stage on the route to adulthood as an unavoidable fact (Hackauf \& Winzen, 2004, p. 41). The increasing number of all-day offers and school-affiliated care models is associated with an expansion of school attendance time during the day. The share of time and everyday activities that adolescences spend in school and school-affiliated educational establishments has increased noticeably, elevating such places to the level of relevant "social living places" (Gspurning, Heimgartner, Leitner, \& Sting, 2010).

Thus, school is not only a place of cognitive education, but also a location where children and adolescences go through social experiences with peers and adults, a place where processes of personality development and identity formation take place, where social competences and social recognition are acquired, and where social problems develop and are made manifest (Coelen, 2002).

In confronting the altered status of educational establishments in sciences, school needs "social pedagogical reflexivity": it must reflect on its societal functionality, its societal conditions and its contribution regarding the opening up and inhibiting of social participation and opportunities in life (Sting, 2010). Numerous tasks consequently emerge for social work and social pedagogy in the school context. The political legitimatisation of school social work is primarily a result of working with the social problems and crises that either develop at school or become subject matter in the school setting (Speck, 2007). A further key concept is participation in educational work (e.g., by encouraging social and personal competences), as well as the pursuit of the defined goals that are characteristic of social work and social pedagogy, but that are making specific accesses necessary at school: regarding the preservation of life and participation opportunities for all pupils, the facilitation of inclusion at school, and the support of a democratic and open school culture. 
School social work responds to these concerns using various concepts. ${ }^{4}$ During a relatively short time span, a plural project scene has developed that involves heterogenic approaches and goal definitions. In Germany, school social work has undergone rapid expansion since the 199os due to the expansion of all-day schools, resulting in approximately 5,000 school social workers currently being employed at schools (Speck, 2012). During the 2000 in Switzerland, a decentralised, widespread network of initiatives arose, including attempts to implement unified "frame recommendations" and "quality criteria" (SSAV, 2010). There are currently about 700 school social workers active in Switzerland, although the stage of expansion varies enormously depending on the region (Kaufmann, 2012). The situation in Austria somewhat lags behind developments in Germany and Switzerland. Although there were various initiatives aimed at the establishment of school social work in Austria during the second part of the 1990s (Vyslouzil \& Weißensteiner, 2001), there was no startup linked to these initiatives. With a few exceptions (e.g., X-point in Lower Austria), most of the projects ceased during the 20oos. It is only in the last few years that we find new, intensified efforts towards the establishment of school social work in all provinces, based on a broad political will at various levels.

\section{The Situation of School Social Work in Austria}

The development of school social work in Austria is very heterogenic. In the nine provinces, various initiatives and projects have emerged. Although an overview has been developed by Bugram and Hofschwaiger (2010), and evaluations exist concerning specific projects (e.g., Gspurning et al., 2011; Sting \& Leitner 2011; Wetzel, Braun, \& Hönig, 2010), there is no clear and accepted documentation of the situation. The last evaluation throughout Austria took place in the 2010/11 school year. At that time, school social work was positioned in 256 schools, which means that approximately $4 \%$ of all schools throughout Austria had school social work (Adamowitsch, Lehner, \& Felder-Puig, 2011).

The expansion of school social work varies enormously in the different regions. Whereas in some provinces there are only isolated, temporary projects, the provinces of Upper Austria, Vorarlberg and Vienna are aiming to achieve region-wide expansion of school social work as a permanent regular offer. A total of 131 school social workers were employed at Austrian schools during the $2010 / 11$ school year. The ratio of the service quantity ranges from one school social worker per 320 pupils in Burgenland to one school social worker per 1,953

4 In German-speaking countries, the English term "school social work" comprises a variety of tasks and offers, including aspects of social work and social pedagogy. 
pupils in Lower Austria. Finally, the forms of organisation also vary. In Vienna, school social work is assigned to the school board, whereas in Upper Austria implementation takes place in the context of youth welfare. In other provinces, school social work is financed by public funds but carried out by free associations and civil society organisations (Adamowitsch et al., 2011).

One reason for the heterogeneity of the development is that there is not yet a precise, legal basis for school social work. In the Youth Welfare Laws of the provinces, cooperation with schools is voluntary and has no obligatory dimension. Due to the nationwide School Organisation Law, school social workers are considered as "school external persons" (except in Vienna, where they are subjected directly to the school board), which causes numerous uncertainties concerning their authorisations and competences, as well as their role in the school system (Bugram \& Hofschwaiger, 2010; Gspurning et al., 2011; Sting \& Leitner, 2011).

Due to the historically separate development of school and social pedagogy (respectively defined as social work) in German-speaking countries, cooperation between school social workers and teachers is not uncomplicated. Speck points out differences in professional culture, based on the separate development of the professions, that establish mutual preconceptions and stereotypes in each of the professions regarding the other professional category. At the same time, the cooperation relationship is characterised by a hierarchic imbalance in power, resulting from the fact that school is the central place for teachers to practise their profession, whereas school social workers have to function in a location that is not equipped for them in the first place (Speck, 2007). Scheipl states that, in Austria, the institution of school and the institution of school social work have different goals: while school addresses the factual level and defines itself through knowledge transfer and learning content, school social work focuses on the individual with his/her needs, talents, problems and requirements for coping with life, and in so doing follows a holistic, personality-related approach. However, school seems to be increasingly unable to cope: it neglects the personal level and concentrates only on the factual level. It can "perform its main business of teaching and transferring knowledge less and less under these aggravated conditions" (Scheipl, 2007, p. 710). School social work can take over a large part of facilitating education, if it creates the framework that empowers children and youth to realise educational achievements (Scheipl, 2007). 


\section{Research Methods}

The present article incorporates evaluation studies from Carinthia (Sting \& Leitner, 2011) and Styria (Gspurning et al., 2011). In Styria, quantitative questionnaires (teachers $(n=72)$ and pupils $(n=80))$, semi-standardised interviews (school social workers $(n=7)$, div. professionals $(n=12)$ ), group discussions (teacher ( $\mathrm{n}=2$ group discussions), pupils ( $\mathrm{n}=5$ group discussions), parents $(\mathrm{n}=2$ group discussions) $)$, as well as documentation analysis $(\mathrm{n}=325$ interventions) were carried out. The enquiry dates were distributed over a period of two years (2010 to 2011), so that developments can be perceived. The analysis of the quantitative data was supported by the software SPSS, while the qualitative content analysis was undertaken using MAXQDA.

In Carinthia, qualitative questionings of users (pupils, teachers, principals and parents) was carried out. The enquiry included six schools representing different school types and various regions of Carinthia. The data collection was undertaken in two stages in order to recognise developments in the implementation process of school social work: the first stage lasted from October 2009 to January 2010, and the second from December 2010 to February 2011. A total of 123 guided interviews were conducted (66 with pupils, 24 with teachers, 12 with principals, 14 with parents and 7 with school social workers). The data analysis followed the principles of grounded theory by using the computerbased data analysis programme MAXQDA (Sting \& Leitner, 2011).

\section{Results}

The evaluations show that school social work can establish itself successfully in schools in the most cases, in spite of the aforementioned problems. Gspurning et al. (2011) determined that school social work is consistently accepted and appreciated. The number of interventions in the projects they evaluated has increased considerably since the beginning of school social work. This can be interpreted as an indicator of the increasing involvement of school social work in the school system.

The questioning of users in Carinthia showed a predominantly positive appraisal and a high level of satisfaction regarding school social work. During the course of the present project, school social work was accepted as a useful and necessary offer in all of the evaluated locations, and was integrated into the normal operation of the school (Sting \& Leitner, 2011). 


\section{Services of School Social Work}

The services of school social work were mainly observed in the following fields (Sting \& Leitner, 2011):

(1) Support and counselling regarding specific problems: support refers to various issues and fields, such as teaching-related problems, family problems, orientation concerning future occupation and arbitration in pupil-teacher conflicts. "Networking with school external partners" - cooperation with other institutions such as youth welfare services, counselling services or therapeutic services - is mentioned as a special achievement. One principal emphasised the following aspect: "This occurs rapidly and is unbureaucratic, and this is the main point. I have the information in a short period of time (...) so each case or each matter can be dealt with much more rapidly".

(2) Encouragement of class cohesion and integration of specific pupils: in new classes or school classes that are constituted differently - classes with difficult group dynamics - activities are carried out to improve class cohesion and the class climate. Furthermore, specific pupils affected by exclusion or bullying are supported in their integration into the class. These activities have a playful or experiential-educational character. Pupils report experiences that are fun and enjoyable, while teachers experience the resulting building of trust and improvement of the class climate, partly in a way "that the children don't even recognise" (teacher).

(3) Attachment figure and contact partner: school social workers were able to establish themselves as onsite contact partners for a wide range concerns, particularly for pupils. Their "neutrality" in the school system seems to give them a special position of trust, which the pupils sometimes rank more highly than their trust in parents or friends: "(...) so if I really had a problem that I didn't know how to solve, then that would be my first choice, because sometimes there is something that you don't want to tell your parents at the time, or maybe it even has to do with them, or maybe with your friend or friends, and so you can't just tell anybody. Because the school social worker is neutral, I think he tries to step into your shoes and into the shoes of the others, which is something that I regard as very positive about him" (pupil).

(4) School social work as an external perspective: school social work seems to have an intermediate position. On the one hand, it is part of the school system and therefore familiar with everyday routines and events. On the other hand, because it is provided by an external institution it is considered to have an external perspective, and this "foreignness" leads to specific advantages. For instance, one parent emphasises, that children "talk more easily with strangers 
about some things", while one pupil clearly draws a line between the school social worker and the teachers, as the former are not included in school sanction mechanisms: "we don't have such a pupil-teacher relationship, but rather relationships of friendship with them". One principal refers to them as "great dialogue partners for the staff, and also for me. So I have to admit that I sometimes make use of them if I have to talk about something". As noted several times by teachers, the other "external" perspective of school social workers results from their differing professionalism, in line with their specific training and the resulting professional competences: "because I don't have the qualifications to deal with problematic pupils. I mean, I try to look up quite a lot, but how one can really deal with it or know which possibilities one has. This I don't know, and they have a high level of professional expertise" (teacher).

\section{Methodical Repertoire - Between Crisis-Oriented and Cultural}

A key issue for establishing extensive, low-threshold school social work is the preference for its regular and continuous presence in specific schools. The evaluation in Carinthia determined the desire for a daily presence; in praxis, however, in most cases it is confined to a few hours on one or two days per week (Adamowitsch et al., 2011). In addition, it is necessary to develop a sophisticated methodical repertoire that refers not only to work with pupils, but also opens up possibilities for work with teachers, principals, parents and other social actors, as well as with the overall population.

\section{Direct Work with Pupils}

Gspurning et al. (2011) presented a distinctive method for direct work with pupils, distinguishing between "open operation", "counselling respective individual-case intervention", "intervention during recess", "interventions when pupils are send out of class", "groups and class operations", "issue-specific projects", and "recreation offers". With "open operation", the authors mean that pupils can be in the culturally based room of school social workers, where the school social workers act as co-creators. From a professional point of view, this can be compared with the operating of a youth centre. "Issue-specific projects" have a specific duration and a continual orientation, for example "a getting-toknow-each-other phase" at the beginning of the school year including close cooperation with teachers, but also "prevention of violence projects" or "community-oriented projects".

It is extremely important that a restriction to individual-case work leads to sometimes stigmatised, and always less co-creating, school social work. Sting 
and Leitner (2011) refer to this as the "risk of narrowing the offer to short-term problem solving". Culturally oriented school social work needs "open operation", "group operations" and "issue-specific projects" in which the pupils are involved without the occurrence of a problem. Wetzel et al. (2011) point out that more than half of parents express a desire for out-of-school offers. This also shows that the task of school development can only be pursued with a complex methodical approach.

\section{Methods with Teachers}

Gspurning et al. (2011) distinguish between case-specific and case-unspecific methods: case reviews and helper conferences are case-specific methods, whereas conferences, workgroups or informal contacts are case-unspecific options.

\section{Methods with Parents}

With parents, a mobility component is evident. Due to the fact that some parents are difficult to reach through invitations from the school (Sting \& Leitner, 2011), the question arises as to who is in charge of mobile work with parents. If, due to its resource capacities, school social work is unable meet this requirement in a flexible way on a low-threshold level, youth welfare could be a possible provider, although its activates are usually more extensive. The analysis of Wetzel et al. (2011) makes it clear that the desire for specific offers is based on the individual perspective. Pupils, teachers and parents differ concerning their demands of school social work.

\section{Multi-Thematic Alignment}

Sometimes school social work is associated only with specific problems (e.g., violence, dropout). Analysis of documentation shows that school social work covers a broad thematic field. Gspurning et al. (2011) analysed 325 individual-case interventions at one location (NMS Algersdorf), enabling the variety of themes to become apparent (see Table 1). The most frequent areas of intervention are: resolution of disputes between pupils, counselling on family problems (e.g., financial problems), standing up against physical violence of schoolmates, and reducing disturbances during lessons. Interventions are also often necessary in cases of foster care, verbal abuse of schoolmates, self-harm and violence in the family. Love, sexuality, truancy or bullying are examples of other problems. 
Table 1. Issues of single-case interventions

\begin{tabular}{|c|c|c|}
\hline Issues & Cases & Percentage \\
\hline disputes with schoolmates or friends & 50 & 15.4 \\
\hline diverse family problems & 38 & 11.7 \\
\hline physical violence by schoolmates & 25 & 7.7 \\
\hline disruption of lessons & 23 & 7.1 \\
\hline foster care & 19 & 5.8 \\
\hline verbal abuse by schoolmates & 18 & 5.5 \\
\hline self-harm & 18 & 5.5 \\
\hline violence in the family & 16 & 4.9 \\
\hline diverse personal problems & 14 & 4.3 \\
\hline conflicts between teacher and pupil & 14 & 4.3 \\
\hline love and sexuality & 13 & 4.0 \\
\hline truancy & 10 & 3.1 \\
\hline change of school or class & 10 & 3.1 \\
\hline bullying by schoolmates & 8 & 2.5 \\
\hline theft or missing items & 8 & 2.5 \\
\hline grades and exams & 7 & 2.2 \\
\hline molesting, grabbing or spitting of schoolmates & 7 & 2.2 \\
\hline internet & 6 & 1.8 \\
\hline future, qualifications & 5 & 1.5 \\
\hline suspension & 4 & 1.2 \\
\hline wellbeing & 3 & .9 \\
\hline damage to property & 3 & .9 \\
\hline smoking & 2 & .6 \\
\hline worry about other persons & 2 & .6 \\
\hline uncategorised & 2 & .6 \\
\hline Total & 325 & 100 \\
\hline
\end{tabular}

Due to a lack of alignment of categories, comparison of issues between different schools is only possible to a limited extent. In a similar table of issues determined by X-point (2010), the leading topics were those of emotions, school problems, violence and family problems. Friendship, conflict solving, class cohesion, life planning and recreation are other common issues in this listing, followed by multiculturalism, love, divorce and splitting up, bullying, psychological and medical afflictions, as well as sexuality. In order to make statements about school social work in Austria overall, it would be a useful to harmonise the thematic categories. 


\section{Locational Requirements of School Social Work}

It is considered necessary for school social work to at least have a room of its own (Speck, 2007), while multi-room concepts provide opportunities for the realisation of a broad methodical repertoire. Burgram and Hofschwaiger (2010) found that not all school social work facilities have a room of their own: some have joint users and in one case they have no room at all. Furthermore, the joint use of school rooms (e.g., classrooms, gymnasium and break rooms) should be considered, so that more activates typically take place than the location of the school social work itself provides. A suitable location is essential, particularly with regard to open operation. Furthermore, it is often impossible to combine counselling and other activates in a small room. The question therefore arises as to how culturally preventive aligned school social work can be realised in constricted locations.

The question of the joint usage of locations for afterschool care should also be considered. Multi-room concepts should be continuously developed at least for afterschool care (Gspurning et al., 2010), from which school social work could benefit in the mornings.

Another important aspect is the quality of the location. Interventional and preventive offers, as well as class activities, can only be put into practice if inviting locations exist. Locations must provide space for withdrawal, as well as for (confidential) conversations and meetings; therefore, a pleasant atmosphere for conversations is required, but also spaces for group work and games. Furthermore, locations must be clearly visible and easily accessible in the school building. Appropriate locations influence the possibilities of access for the users: "a neutral room, where pupils and teachers (...) have no fear of entering, to overcome inhibitions in order to be free, and to articulate the simple problems that burden them. (...) Other important points to be considered are free access, trust, atmosphere and comfort" (L9) (Sting \& Leitner, 2011).

\section{Staff and Qualifications}

In the field of action of school social work, social work and social pedagogical perspectives overlap, so both qualifications are essentially compatible regarding employment. The professions are applied differently in some concepts (e.g., Grottenthaler et al., 2011), but they can be considered equal in terms of the skills they provide for school social work. Related disciplines are also relevant (e.g., pedagogy, sociology and psychology). Establishing quality assurance is an important issue, in order to ensure reflection and continuous 
development. This develops, for example, through inter- and supervision, and requires appropriate opportunities for additional training.

One of the main tasks is the realisation of specific principles in ongoing praxis. Principles such as relationship orientation, low-thresholds, participation, reflecting on gender issues, resource orientation or voluntariness have not yet been determined with regard to their dimension of application. A great deal of scope therefore exists for the implementation and design of the specific work in each school, which can be addressed autonomously by the actors involved. Various examples show that the realisation is sometimes complicated by the circumstances. The actors are then caught between the poles of professional understanding and the infrastructure of implementation; for example, for many pupils from several schools, relationship work represents an unmanageable burden, and low-thresholds cannot be implemented if the location or opening hours are inadequate (Gspurning et al., 2011). From an evaluation by Sting and Leitner in Carinthia, it is evident that acceptance by the specific principal is crucial to the successful formation of praxis (Sting \& Leitner, 2012). Various providers also aim to strengthen the presence of men in school social work, but this is only achievable in a limited way within an educational field that is a women's domain (Heimgartner, 2009).

\section{Cooperation and Networking}

An important goal of all of the actors involved in school activities should be that the various professions that have committed themselves to school education and support cooperate constructively. Teachers, doctors, psychologists, integration teachers, afterschool caregivers and other professional groups contribute, together with school social workers, to the success of school life. Currently, the question is how the joint and cooperative taking of responsibility can be accelerated by building local teams. In contrast, Sting and Leitner (2011) detect "competition between the professions" in some places.

Overall, school social work is characterised by intensive cooperation between various actors. Both case-related and topic-related school social work seems to have a strongly demanded mediation role between various groups of actors. This is true for cooperation in school as well as for cooperation external to school. Adamowitsch et al. (2011) found that the density of cooperation is developed to various extents. Whereas cooperation between school administrations and teachers is very intense, cooperation between school doctors and school psychologists is at a rather low-level. Regarding school's external partners, cooperation with youth welfare, counselling facilities, youth centres and street work ranks at the front line. 
A special feature of Austrian school social work is a rather high share of "detached work" (Speck, 2012). About 13.5\% of the total work takes place outside school, e.g., through counselling and supporting pupils outside school or by visiting parents. School social work could contribute overall to an expansion of school's radius of operation into the social environment; for example, through contact with clubs and businesses, or through public relations activities. However, this requires significant time and staff resources. It would be desirable for the cultural, artistic or economical resources of the social environment of the school to be increasingly available through school social work. In Graz, social environmental youth welfare is currently being tested (Krammer, 2012; Sixt, 2012). A regional approach towards schools could also occur in this regard, and an expansion of joint case-specific activities can be expected. In Styria, a complete village has been defined as the school environment, so pupils can move freely and, among other things, benefit from offers of bound and open youth work (e.g., music lessons), thus opening up possibilities for cooperation with various forms of community work (Sing \& Heimgartner, 2009).

\section{Research and School Social Work}

The heterogenic and province-related development of school social work makes it difficult to gain an overview of its actual expansion, and of its associated opportunities and problems. Systematic documentation and research on school social work is vital for its future development. On the one hand, the established broad spectrum of forms of knowledge and research methods in social pedagogy can be used for this purpose (Heimgartner, 2011), while, on the other hand, uniform models of knowledge acquisition and scientific observation must be enforced in each specific region, thus enabling a concerted documentation and analysis of school social work in Austria. The promotion of exchanges of attending-evaluation studies and longitudinal surveys, the appropriate integration of the involved parties (e.g., pupils) in research and development, and the presentation of publication and conference activity, could increase the tolerance and safety of school social work in Austrian society altogether.

\section{Conclusion}

Several key preconditions must be satisfied for school social work to render positive accomplishments. Firstly, school social work must maintain its independent role in the school system, which can be achieved with free providers. Incorporation in the school organisation is only useful if sufficient provisions 
are made to ensure that it is not used for school and instructional purposes. Secondly, school social work needs low-threshold access, i.e., access to school social work must be guaranteed. The care relationship between school social workers and pupils, in particular, is responsible for the reality of how much time is available for relationship work. Thirdly, a widespread understanding of themes needs to be established. The implementation of school social work is often justified by a tight focus on problem shooting, which could lead to the point where school social work is only involved as a short-range rescue service in the case of a crisis. The deficit-oriented approach - implemented as crisisoriented counselling, and with a rather high-threshold character - must be distinguished from the cultural preventive approach, which understands school social work as a low-threshold, diverse offer with a broad methodical spectrum that, besides supporting individuals, also keeps an eye on the development of the social climate at the school (Gspurning et al., 2011; Leitner \& Sting, 2011; Heimgartner, 2012).

\section{References}

Adamowitsch, M., Lehner, L., \& Felder-Puig, R. (2011). Schulsozialarbeit in Österreich Darstellung unterschiedlicher Implementierungsformen. Forschungsbericht [School Social Work in Austria. Illustration of Various Implementation Methods. Research Paper]. Wien: Ludwig Boltzmann Institute - Health Promotion Research.

Bugram, C., \& Hofschwaiger, V. (2010). Schulsozialarbeit in Österreich 2010. Masterarbeit [School Social Work in Austria 2010. Master's Thesis]. Graz: Universität Graz. Retrieved May 312013 from http://ema2.uni-graz.at:809o/livelinkdav2/nodes/272555/Bugram_Christina\%2010.09.2010.pdf Coelen, T. (2002). „Ganztagsbildung“ - Ausbildung und Identitätsbildung von Kindern und Jugendlichen durch die Zusammenarbeit von Schulen und Jugendeinrichtungen ["All-Day Education" - Education and Identity Formation of Children and Adolescences by Cooperation of Schools and Youth Services]. Neue praxis, 32(1), 53-66.

Grottenthaler, N., Ladner, G., Loske, D., Naschberger-Schober, L., \& Wanko, C. (2011). Konzept zum Projekt Schulsozialpädagogik an der Hauptschule Fieberbrunn. Sozialpädagogik Stams.

Gspurning, W., Heimgartner, A., Leitner, S., \& Sting, S. (2010). Soziale Qualität von

Nachmittagsbetreuungen und Horten [Social Quality of Afternoon Care and Afterschool Centers].

Wien: LIT - Verlag.

Gspurning, W., Heimgartner, A., Pieber, E. M., \& Sing, E. (2011). Wissenschaftliche Begleitung der

Schulsozialarbeit Graz [Scientific Attendance of School Social Work in Graz]. Graz: Institut für

Erziehungs- und Bildungswissenschaft der Universität Graz. Retrieved May 312013 from http://www.

uni-graz.at/ heimgara/SP/SIM.pdf

Hackauf, H., \& Winzen, G. (2004). Gesundheit und soziale Lage von jungen Menschen in Europa 
[Health and Social Situation of Young People in Europe]. Wiesbaden: VS.

Heimgartner, A. (2004). Schulsozialarbeit in den Mittelpunkt [School Social Work in the Center].

In G. Knapp (Ed.), Soziale Arbeit und Gesellschaft. Entwicklungen und Perspektiven in Österreich (pp. 580-599). Klagenfurt, Laibach, Wien: Hermagoras.

Heimgartner, A. (2009). Komponenten einer prospektiven Entwicklung der Sozialen Arbeit

[Components of a Prospective Development of Social Work and Social Pedagogy]. Wien: LIT-Verlag. Heimgartner, A. (2011). Über eine kollektive und systematische Forschung- und Wissenskultur zur Jugendarbeit und -wohlfahrt [About a Collective and Systematic Research Culture and Knowledge Culture Concerning Youth Work and Youth Welfare]. In M. Anastasiadis, A. Heimgartner, H. KittlSatran, \& M. Wrentschur (Eds.), Sozialpädagogisches Wirken (pp. 104-116). Wien: LIT Verlag. Heimgartner, A. (2012). Elemente der Schulsozialarbeit und ihre wissenschaftliche Wahrnehmung [Elements of School Social Work and their Scientific Perception]. In M. Marterer (Ed.),

Schulsozialarbeit in Österreich: Status, Zwischenbilanz und Perspektiven. Graz/Wien, Dokumentation der bundesweiten Fachtagung vom 9. Mai 2012 (pp. 27-37).

Höhne, T. (2004). Über das Wissen (in) der Wissensgesellschaft und einige Konsequenzen für die Pädagogik [About Knowledge in/of Knowledge Society and Some Consequences for Pedagogy]. In H.-U. Otto \& T. Coelen (Eds.), Grundbegriffe der Ganztagsbildung (pp. 133-148). Wiesbaden: VS. Huxtable, M., \& Blyth, E. (2002). School Social Work worldwide. Washington: NASW Press. Kaufmann, M. (2012). Schulsozialarbeit in Österreich im europäischen und internationalen Vergleich: Schulsozialarbeit in der Schweiz [School Social Work in Austria in a European and International Comparison: School Social Work in Switzerland]. In M. Marterer (Ed.), Schulsozialarbeit in Österreich: Status, Zwischenbilanz und Perspektiven. Graz/Wien, Dokumentation der bundesweiten Fachtagung vom 9. Mai 2012 (pp. 67-72).

Krammer, I. (2012). Sozialraumorientierung - ein Fachkonzept für ein ganzes Amt [Social Environmental Orientation - A Professional Concept for a Complete Department]. SIÖ,

Sondernummer 1/12, 11-13.

Olk, T. (2004). Jugendhilfe und Ganztagsbildung - alte Rollenzuweisungen oder neue Perspektiven? [Youth Welfare and All-Day Education - Old Role Assignments or New Perspectives?]. Neue Praxis, $23(6), 532-542$.

Scheipl, J. (2007). Schulsozialarbeit. Noch Intervention oder schon Innovation? [School Social Work. Still an Intervention or Already an Innovation?]. In G. Knapp \& K. Lauermann (Eds.), Schule und Soziale Arbeit. Klagenfurt, Lubljana, Wien.

Sing, E., \& Heimgartner, A. (2009). Gemeinwesenarbeit in Österreich [Community Work in Austria]. Graz: Leykam, Universitätsverlag.

Sixt, H. (2012). Sozialraumorientierte Jugendwohlfahrt - Eine Herausforderung für die Sozialarbeit [Social Environmental Youth Welfare - A Challenge for Social Work]. SIÖ, Sondernummer 1/12, $14-16$.

Speck, K. (2007). Schulsozialarbeit. Eine Einführung [School Social Work. An Introduction].

München: Ernst Reinhardt. 
Speck, K. (2012). Europäische und internationale Beispiele [European and International Examples]. In M. Marterer (Ed.), Schulsozialarbeit in Österreich: Status, Zwischenbilanz und Perspektiven. Graz/ Wien, Dokumentation der bundesweiten Fachtagung vom 9. Mai 2012 (pp. 73-82). SSAV (2010). Qualitätsrichtlinien für die Schulsozialarbeit [Quality Guidelines for School Social Work]. Bern: Avenir Social: Professionelle Soziale Arbeit Schweiz - SchulsozialarbeiterInnenVerband.

Sting, S. (2010). Soziale Bildung [Social Education]. In W. Schröer \& C. Schweppe (Eds.), Enzyklopädie Erziehungswissenschaft Online (EEO), Fachgebiet Soziale Arbeit. Weinheim/München. DOI 10.3262/EEO14100114. Retrieved from www.erzwissonline.de

Sting, S., \& Leitner, S. (2011). Evaluation des Pilotprojektes "Schulsozialarbeit in Kärnten" - Endbericht der qualitativen Evaluierung [Evaluation of the Pilot Project "School Social Work in Carinthia" Final Report of the Qualitative Evaluation]. Klagenfurt: Universität Klagenfurt.

Sting, S., \& Leitner, S. (2012). Schule als sozialen Lebensort verantworten [Account for School as a Social Living Place]. Sozialpädagogische Impulse, (1), 34-36.

Vyslouzil, M., \& Weißensteiner, M. (2001). Schulsozialarbeit in Österreich [School Social Work in Austria]. Wien: SOZAKTIV, ÖGB Verlag.

Wetzel, K., Braun, K.-H., \& Hönig, B. (2010). Evaluation des Pilotprojektes „Schulsozialarbeit in Kärnten". Ergebnisse der quantitativen Evaluation [Evaluation of the Pilot Project "School Social Work in Carinthia”. Results of the quantitative Evaluation]. Feldkirchen: Fachhochschule Feldkirchen. x-point (2010). Jahresbericht [Annual Report]. St. Pölten: YOUNG VEREIN FÜR KINDER UND JUGENDLICHE - X-point. Retrieved May 312013 from http://www.X-point.at/dokumente/upload/ Jahresbericht_o910_f2

\section{Biographical note}

Arno Heimgartner, Univ.-Prof. Mag. Dr., since 2011 Professor of Social Pedagogy at the Department of Educational Science of the University of Graz. Areas of research: theories and concepts of social pedagogy, children and youth welfare, children and youth work (e.g. school social work, after school care), professionalisation and volunteering, empirical methods in Social Pedagogy.

Stephan Sting, Univ.-Prof. Dr. phil., since 2005 Professor of Social and Integration Pedagogy at the Department of Educational Research of the University of Klagenfurt. Areas of research: Socio-paedagogical and educational research, social pedagogical theory at the child age and youth age, social work and health, addiction prevention. 